\title{
Altruism and Solidarity of Urban Societies in the Era of the Covid-19 Pandemic Through Digital Gotong Royong
}

\author{
Dodi Faedlulloh ${ }^{1, *}$ Vina Karmilasari ${ }^{2}$, Junaidi ${ }^{3}$, Muhammad Guntur Purbuyo ${ }^{4}$ \\ 1, 2 Public Administration Department, Universitas Lampung \\ 3,4 Sociology Department, Universitas Lampung \\ *Corresponding author.Email: dodi.faedlulloh@fisip.unila.ac.id
}

\begin{abstract}
The Covid-19 virus has attacked almost all aspects of human life, including the community's economy. Globally, during the Covid-19 pandemic, 94\% of workers experienced layoffs. Likewise in Indonesia, more than 3.5 million workers were affected by layoffs. A pandemic attack is a momentum to activate the attitude of altruism and solidarity among citizens. Gotong royong is a local Indonesian term that takes the form of joint activities to achieve mutually expected results. When modern life is always considered to have destroyed the traditional values of gotong royong and solidarity, it does not apply to the context of solidarity in the pandemic era. The interesting thing is that the attitude of altruism and solidarity grows in modern urban society, which is shown by various solidarity initiatives through digital platforms. The concept of gotong royong is now transforming into a new face: digital gotong royong. This study aims to analyze the practice of altruism and urban solidarity through digital gotong royong which was carried out when the Covid-19 pandemic hit Indonesia. The research method used is a qualitative method with a strict literature review to read the phenomena of altruism and solidarity practices. An important finding from this research is the need for a new perspective in interpreting altruism and solidarity in the context of urban society. The prerequisites for the value of closeness and kinship in the practice of digital gotong royong are not the main values.
\end{abstract}

Keywords: Altruism, Covid 19, Digital Gotong Royong, Solidarity, Urban

\section{INTRODUCTION}

The Covid-19 virus has destroyed almost every aspect of human life. Millions of people have been infected by the Covid-19 virus, which has caused unprecedented economic damage [1]. As of January 17, 2021, there had been 907,929 cases recorded in Indonesia. A total of 25,000 people have died as a result of Covid-19. Indonesia is ranked first in Southeast Asia for the number of deaths [2]. Since Indonesia's health system is not running optimally, many have speculated that this number may be even higher.

Many regions eventually adopted the Large-Scale Social Restriction (PSBB) policy which was later transformed into the Enforcement of Community Activity Restrictions (PPKM) following the release of Presidential Decree No. 12 of 2020 concerning the Determination of Non-Natural Disasters for the Spread of Corona Virus Diseases 2019 (Covid-19) as a National
Disaster. With these restrictions, people's mobility will automatically be different from before. Especially for urban communities in Indonesia.

The International Labor Organization (ILO) estimates that 94 per cent of employees will be sent home or laid off by 2020 [3]. This is because quarantine policies in many countries have reduced working wages. Moreover, according to ILO statistics, there was a net loss of working hours in the second quarter of 2020, namely April-June 2020, of $17.3 \%$ or 495 million fulltime equivalent employees, compared to the fourth quarter of 2019. In terms of worker income, it decreased by $10.7 \%$ or 3,5 trillion dollars in the first quarter of 2020 compared to 2019 in the same period. This condition of course also occurs in Indonesia's health context.

Since the normally high levels of collective mobilization must be reduced, urban areas are affected 
more quickly. On the other hand, the capacity of the Indonesian government is still quite slow in responding to a pandemic [4], including the issue of a welfare safety net system. Even in the context of social assistance, at the end of 2020, the Indonesian people received bad news about the existence of corruption from the minister of social affairs [5].

Behind the circumstances that still leave a lot of institutional homework on the state's shoulders, public interest rises hand in hand to work together to combat the Covid-19 pandemic in Indonesia. The involvement of numerous projects from local societies that carry out various acts of cooperation focused on altruism is particularly interesting. Pandemics influence not only people physically but also their social relationships. In terms of social relations, the outbreak of a pandemic has caused social disruption and has aided the development of social solidarity.

In reality, the character of Indonesian local societies, which is thick with the spirit of communality and mutual participation, is embedded in the development of social solidarity in Indonesian society. Surprisingly, the sense of unity is still growing in urban areas. People of character in the city usually take care of themselves without needing to rely on others, and there is a strict division of labour [6] that seems to maintain a sense of gotong royong spirit. Various social cooperation programs, such as exchanging meals, caring for neighbours who are positively impacted by Covid-19 [7], collecting funds to purchase Personal Protective Equipment (PPE) for medical personnel [8], and supplying hand sanitisers and masks, are all examples of this. People who are required to keep their actions outside the home due to their employment, as well as a variety of other events, demonstrate that social cohesion exists in addition to altruism.

In the digital realm, urban communities are now shifting their practice of solidarity. The disruption due to the presence of the 4.0 industrial revolution wave added methods or ways to carry out activities. Not just change, disruption is also a big change that transforms order [9]. Citizens' altruism efforts in helping each other amid a crisis due to the pandemic also use digital platforms. In addition to direct solidarity efforts made by certain groups or communities that are specifically carried out in certain locations, now there is also digital solidarity with a wider coverage area. With advances in technology and support from increasingly advanced infrastructure, solidarity actions have become easier to carry out. Only through gadgets can anyone who intends to help others be done in seconds. In other words, a new culture in urban solidarity is now being created: digital gotong royong.

The enabling potential for digital shared cooperation practices is determined by the objective circumstances of urban societies that dominate internet usage in
Indonesia. As a result, a new outlook on altruism and cooperation in the sense of urban culture is needed. The key value is not the prerequisites for the significance of closeness and kinship, which are typically guiding forces in the tradition of reciprocal participation in rural communities.

Based on the foregoing, the author is interested in conducting preliminary research to better understand the dynamics of altruism and solidarity attitudes among urban communities in Indonesia through the use of digital gotong royong. The mentality of altruism is a central feature of digital social cooperation that needs to be discussed further. It is a motivation that seeks to help better the well-being of others without worrying about itself [10]. In the fact that altruism is recognized as a symptom on an individual level, it is undeniable that it will flourish in a moment of togetherness, even serving as the foundation for solidarity initiatives.

According to Robertus Robert [11], altruism can be used as a basis for stronger social solidarity. According to him, no matter how great the economic and political rationality is in maintaining self-interest as the anthropological basis, the fact that humans are social creatures is never replaced.

\section{METHOD}

The research design is a qualitative research approach that uses literature reviews to trace data and facts. Literature reviews help offer an analysis of the issue under investigation, analytical philosophical support, and information for research debate [12]. The information comes from a variety of publications, books, and authoritative news outlets. The writers then have critical reviews by elaborating and reinterpreting the tradition of digital gotong royong by local societies through the lens of altruism and solidarity.

\section{RESULT AND ANALYSIS}

\subsection{Urban Society and Gotong Royong}

Urban life has the facilities of modern social life. Fast and formal social connections are the standard. Education, technology, manufacturing, and urbanization have also accelerated the acceleration of social change. People of various races, occupations, castes and sects coexist in a complex social setting. Many social scientists have attempted to characterize and abstract grey culture. In the real world, though, modern society is fundamentally complex. At the very least, urban society has many characteristics, including 1) a shift to a more complex craftsman system, 2) a cultural transformation that emphasizes rationality and utilitarianism, 3) a transfer of family power and function to public institutions, 4) degradation of traditional values of social solidarity in the family and 
environment, and 5) decreasing int 6) Increasing meaning and community plurality, and 7) increasing spatial community differentiation [13].

Table 1. Digital gotong royong in Indonesia during the covid-19 pandemic

\begin{tabular}{|c|c|c|c|c|}
\hline $\begin{array}{l}\text { Platfor } \\
\text { m Name }\end{array}$ & Type & How To Help & $\begin{array}{l}\text { Who is being } \\
\text { helped }\end{array}$ & $\begin{array}{l}\text { Assistanc } \\
\text { e } \\
\text { Coverage } \\
\text { Area }\end{array}$ \\
\hline Bagirata & $\begin{array}{l}\text { Gotong } \\
\text { royong } \\
\text { based } \\
\text { wealth } \\
\text { distributi } \\
\text { on } \\
\text { platform }\end{array}$ & $\begin{array}{l}\text { Donations, } \\
\text { volunteer } \\
\text { administrators } \\
\text { and platform } \\
\text { developers }\end{array}$ & $\begin{array}{l}\text { Workers in the } \\
\text { tourism, } \\
\text { hospitality, } \\
\text { creative, arts, } \\
\text { culture, } \\
\text { entertainment } \\
\text { and } \\
\text { gigeconomy } \\
\text { sectors }\end{array}$ & $\begin{array}{l}\text { Througho } \\
\text { ut } \\
\text { Indonesia }\end{array}$ \\
\hline $\begin{array}{l}\text { Mamaja } \\
\text { hit }\end{array}$ & $\begin{array}{l}\text { Provision } \\
\text { of PPE } \\
\text { for } \\
\text { Health } \\
\text { Workers }\end{array}$ & Donations & $\begin{array}{l}\text { Hospital and } \\
\text { puskesmas } \\
\text { health } \\
\text { personnel }\end{array}$ & $\begin{array}{l}\text { Througho } \\
\text { ut } \\
\text { Indonesia }\end{array}$ \\
\hline $\begin{array}{l}\text { Kawal } \\
\text { Covid- } \\
19\end{array}$ & $\begin{array}{l}\text { The latest } \\
\text { informati } \\
\text { on } \\
\text { platform } \\
\text { about } \\
\text { Covid-19 }\end{array}$ & $\begin{array}{l}\text { Volunteer for } \\
\text { technology, } \\
\text { data and } \\
\text { content }\end{array}$ & $\begin{array}{l}\text { Wide } \\
\text { community }\end{array}$ & $\begin{array}{l}\text { Througho } \\
\text { ut } \\
\text { Indonesia }\end{array}$ \\
\hline $\begin{array}{l}\text { Kawalr } \\
\text { umahsa } \\
\text { kit.id }\end{array}$ & $\begin{array}{l}\text { Informati } \\
\text { on } \\
\text { platform } \\
\text { around } \\
\text { the data } \\
\text { needs of } \\
\text { medical / } \\
\text { health } \\
\text { equipmen } \\
\text { t in } \\
\text { hospitals }\end{array}$ & $\begin{array}{l}\text { Volunteer } \\
\text { data input and } \\
\text { monitoring of } \\
\text { health } \\
\text { facilities } \\
\text { needs }\end{array}$ & $\begin{array}{l}\text { Wide } \\
\text { community }\end{array}$ & $\begin{array}{l}\text { Througho } \\
\text { ut } \\
\text { Indonesia }\end{array}$ \\
\hline $\begin{array}{l}\text { Bantum } \\
\text { edis.com }\end{array}$ & $\begin{array}{l}\text { Informati } \\
\text { on } \\
\text { platform } \\
\text { around } \\
\text { medical / } \\
\text { health } \\
\text { device } \\
\text { needs } \\
\text { data }\end{array}$ & $\begin{array}{l}\text { Donation of } \\
\text { medical } \\
\text { health } \\
\text { equipment }\end{array}$ & $\begin{array}{l}\text { Wide } \\
\text { community }\end{array}$ & $\begin{array}{l}\text { Througho } \\
\text { ut } \\
\text { Indonesia }\end{array}$ \\
\hline $\begin{array}{l}\text { Ayoberg } \\
\text { erak.id }\end{array}$ & $\begin{array}{l}\text { A } \\
\text { platform } \\
\text { that } \\
\text { supports } \\
\text { the needs } \\
\text { of PPE } \\
\text { for } \\
\text { medical } \\
\text { personnel }\end{array}$ & Donations & $\begin{array}{l}\text { Wide } \\
\text { community }\end{array}$ & $\begin{array}{l}\text { Througho } \\
\text { ut } \\
\text { Indonesia }\end{array}$ \\
\hline
\end{tabular}

The information presented above demonstrates the presence of gotong royong projects within urban populations to assist others in the event of a pandemic. This program was sparked by the ideas of artistic minorities or young people from Indonesian urban societies. Non-digital solidarity efforts are not included in this data.

Gotong royong is a local Indonesian term that takes the form of joint activities to achieve mutually expected results. This term comes from the word Gotong royong which means work, and Royong which means together [14][15]. When modern life is always considered to have destroyed the traditional values of gotong royong and solidarity, it does not apply to the context of digital gotong royong.

The nature of digital gotong royong demonstrates how digital transformation can support society by making it possible for people to help one another Technology connects idea generators, individuals in need of assistance, and people who wish to contribute. In essence, urban culture is a community of people who recognize the value of technology in their daily lives. Technology is inextricably linked to their everyday lives and their reflections on social behaviours and relationships. The presence of technology profoundly aids the character of urban society with a busy life and events.

\subsection{The Growth of Altruism and Solidarity in The Pandemic Era}

The pandemic phenomenon shows the paradox of urban society. On the one hand, at the beginning of the pandemic, it confirmed the selfish character of urban people by buying many necessities of life and medical equipment for themselves. However, slowly solidarity was born during a pandemic and has been getting stronger until now.

An exciting thing that deserves a more profound study is the growth of altruism and solidarity among Indonesian urban communities during the pandemic. In general, altruism is a person's good intentions to help others unconditionally. In altruism, sincerity is the essential thing. This sincere attitude drives the courage to contribute, which can harm oneself for the benefit and welfare of others [16]. Sincerity here is, of course, not based solely on religious things. Although it does not rule out, some people have an altruistic attitude because they are based on beliefs in certain religions.

Urban society is a society that consumes a high lifestyle. Capitalism and urban society have a high association [17]. In several studies on cities, especially those that have investigated cities' ecology and political economy, it has been shown that the city itself is a place where social action is conditioned, capitalist enterprises are engineered, and government can have a decisive influence [18][19]. 
In the middle of an urban society bound by a capitalist lifestyle does not mean negating the good in a capitalist society. Even though capitalism encourages globalization that has succeeded in changing the "state of nature" of people's lives, nowadays people live in a "world of strangers" in which all human activities, whether intentionally or not, can change the lives of other humans, even with people who have never been met. Previous [20][11]. In this case, the altruism of society (urban) takes its role.

Altruism is a symptom of distinct and singular person behaviour oriented toward humanity's universality [21]. A social topic is singular if its distinctions cannot be reduced to equations [22]. As a result, "uniqueness of individuality" is still present. Apart from the enigmatic altruistic attitude motivation, different experiences and research suggest that altruistic behaviour will occur together, according to Robert [11]. Specific events in an incident become moments of togetherness and then intensify into moments of solidarity. During the pandemic, this occurred in Indonesian metropolitan areas as well.

Pandemics begin as a personal interest in urban society. They have difficulty working, are constantly concerned about their fitness, and are concerned about their wellbeing. On the other hand, altruism thrives in a period of unity, such as the Covid-19 pandemic. Since the Covid-19 pandemic knows no bounds. The Covid19 pandemic is the polar opposite in urban societies that are marked by a geographic division of classes. This virus is capable of infecting everyone, regardless of religion, ethnicity, or socioeconomic status.

While altruism is mainly viewed as a symptom on an individual level, it is undeniable that this approach will flourish in a group setting. Urban residents used to technologies engage in social interactions dependent on their skills and the resources available to them. Gadgets are the nearest type of media to them. According to research conducted by Gopay in partnership with Kopernik, the public will spend more than Rp. One hundred two billion from March to October 2020. There is a growing wave in digital donations and an increase in the number of digital site users, making it easier for the public to donate without having to do so in the traditional way. During the pandemic, digital donations have increased by 70 per cent, most of which come from the millennial generation [23]. This pattern once again demonstrates that urban society is willing to perform acts of altruism by assisting strangers. This altruism is turned into empathy by digital assistance. This solidarity is then manifested in different forms of digital gotong royong.

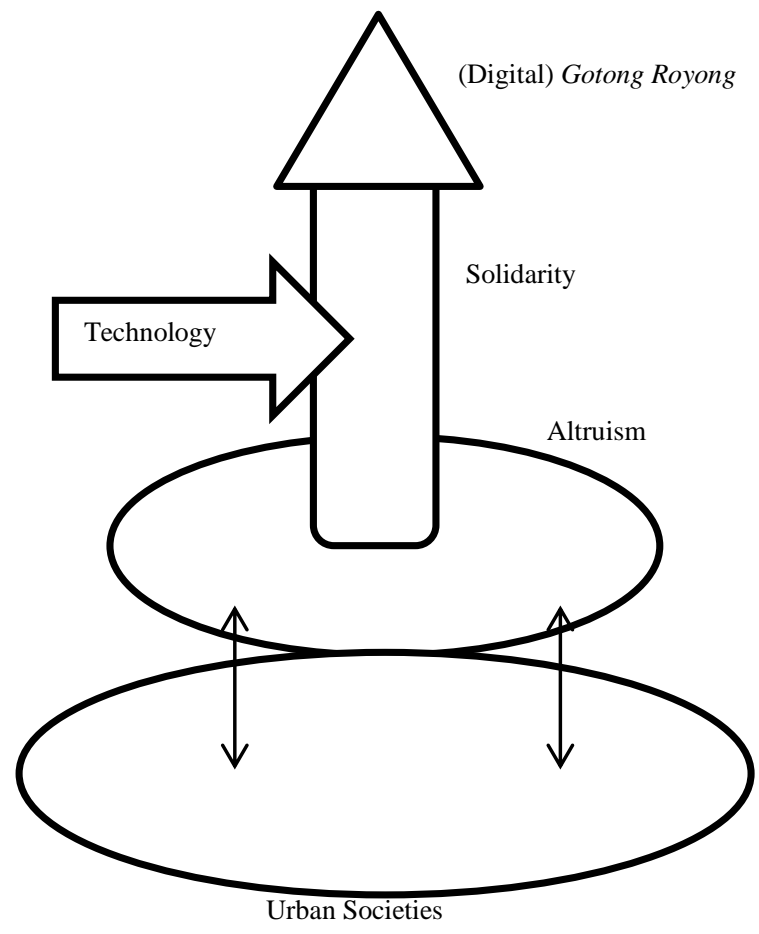

Figure 1 The relationship between urban society, altruism and solidarity

\subsection{From Digital to Actual}

As a mode of action, the motives of altruism cannot be categorized and standardized, but their existence is an essential marker for togetherness in a society [11]. Therefore, altruism is essential to be used as a basis for the development of urban community relations, which must be cared for and internalized as a mode of existence of a society.

The altruism of urban society through digital gotong royong initiatives is an important marker so that solidarity can continue. Therefore, it is still potential. However, the analysis process based on the phenomena described above shows that urban society still has a relatively strong value of solidarity. Although the interaction space is limited, which creates low social cohesion, it has a very potential hidden solidarity. The existence of a digital platform for sharing can accommodate this hidden solidarity. This again affirms that humans, including urban communities, are social creatures that can never be replaced.

The character of local Indonesian citizens, who are deep in communality and collective participation, is also at the core of the development of social solidarity in urban communities. There are, moreover, a variety of agendas that can be built to help create and manage social cohesion. Solidarity should be preserved with a follow-up agenda from interactive activities to actual 
field activities for the urban population's social solidarity to run productively and have a long existence. As a result, digital gotong royong efforts do not devolve into a series of "click" acts.

\section{CONCULSION}

From the above explanation, it can be concluded that urban society has an attitude of tourism and solidarity realized by (one of them) through digital gotong royong. Technology helps these social initiatives by building a platform that can connect idea initiators, people who want to be helped, and people who want to help. This study uses a literature review that is loaded with limited data in the field. Therefore, the authors realize immanently that there are still deficiencies in the results of this study. However, these results have shown an overview of the existence of new practices in cooperation. On the other hand, these findings imply the need for a new perspective in interpreting altruism and solidarity in the context of Indonesian urban society.

\section{AUTHORS' CONTRIBUTIONS}

Dodi Faedlulloh: Conceptualization, Formal Analysis, Writing- Original draft, Writing- Reviewing and Editing, Visualization. Vina Karmilsari: Formal Analysis, Writing- Reviewing and Editing. Junaidi: Writing- Reviewing and Editing. Muhammad Guntur Purbuyo: Writing- Reviewing and Editing.

\section{ACKNOWLEDGMENTS}

The Institute of Research and Community Service, Universitas Lampung (LPPM Unila) provided funding for this study through DIPA BLU funds. The authors would like to express our gratitude to FISIP Unila, LPPM Unila, and the Department of Public Administration Unila for their help in carrying out this study.

\section{REFERENCES}

[1] S. Olivia, J. Gibson, and R. Nasrudin, "Indonesia in the Time of Covid-19," Bull. Indones. Econ. Stud., vol. 56, no. 2, 2020, doi: https://doi.org/10.1080/00074918.2020.1798581

[2] M. Pradana, N. Rubiyanti, W. S, I. Hasbi, and D. G. Utami, “Indonesia's fight against COVID19: the roles of local government units and community organisations," Local Environ., vol. 25, no. 9, pp. 741-743, 2020, doi: 10.1080/13549839.2020.1811960.

[3] ILO, "ILO Monitor: COVID-19 and the world of work. Second edition. Updated estimates and analysis," Int. Labour Organ., no. April, pp. 111, 2020, [Online]. Available: https://www.ilo.org/wcmsp5/groups/public/@dg reports/@dcomm/documents/briefingnote/wcms _740877.pdf.

[4] D. Yulianti, I. F. Meutia, B. Sujadmiko, and Wahyudi, 'Indonesia ' Crisis Response To Covid-19 Pandemic: From Various Level of Government and Network Actions To Policy," J. Public Adm. Financ. Law Indones., no. 17, pp. 34-48, 2020.

[5] V. Lidyana, "Geger di Akhir Tahun, Korupsi Bansos Corona Terkuak," Detik, 2020. https://finance.detik.com/berita-ekonomibisnis/d-5316714/geger-di-akhir-tahun-korupsibansos-corona-terkuak (accessed Jan. 18, 2021).

[6] S. Soerjono, Sosiologi Suatu Pengantar. Jakarta: Rajawali Press, 2009.

[7] R. Susanto, "Program 'Jogo Tonggo' Bangkitkan Empati saat Pandemi," Gatra, 2021. https://www.gatra.com/detail/news/509479/infosatgas-covid19/program-jogo-tonggo-

bangkitkan-empati-saat-pandemi (accessed Apr. 19, 2021).

[8] R. Susanti, "Sumbangan Berdatangan, Ribuan APD Siap Dibagikan kepada Tim Medis," Kompas, 2020. https://regional.kompas.com/read/2020/04/06/08 050941/sumbangan-berdatangan-ribuan-apd-

siap-dibagikan-kepada-tim-medis (accessed Apr. 19, 2021).

[9] Eriyanto, “Disrupsi," J. Komun. Indones., vol. 7, no. $1,2018$.

[10] D. G. Myers, Psikologi Sosial (Jilid 2). Jakarta: Salemba Humanika, 2012.

[11] R. Robet, "Altruisme, Solidaritas dan Kebijakan Sosial," Masy. J. Sosiol., vol. 18, no. 1, pp. 118, 2013, doi: 10.7454/mjs.v18i1.4692.

[12] J. R. Fraenkel, N. E. Wallen, and H. H. Hyun, How to design and evaluate research in education. New York: McGraw Hill, 2012.

[13] J. J. Phalen, The Urban World,. New York: McGraw Hill, 1992.

[14] Koentjaraningrat, Pengantar Ilmu Antropologi. Jakarta: Balai Pustaka, 1987.

[15] D. Faedlulloh, I. F. Meutia, D. Yulianti, and V. Karmilasari, "Gotong Royong Digital : Praktik Baru Solidaritas Warga di Era Pandemi," Jantra, vol. 16, no. 1, pp. 1-14, 2021.

[16] R. A. Baron, N. R. Branscombe, and D. Byrne, Social Psychology (12th ed.). Boston: Pearson Education, 2008.

[17] K. T. Smiley and M. O. Emerson, "A spirit of urban capitalism: market cities, people cities, and cultural justifications," Urban Res. Pract., vol. 13, no. 3, pp. 330-347, 2020, doi: 10.1080/17535069.2018.1559351.

[18] D. Harvey, "The Urban Process Under Capitalism: A Framework For Analysis," Int. J. Urban Reg. Res., vol. 3, no. 1-3, pp. 101-131, 1978, doi: https://doi.org/10.1111/j.14682427.1978.tb00738.x.

[19] A. J. Scott and M. Storper, "The nature of cities: 
The scope and limits of urban theory," Int. J. Urban Reg. Res., vol. 39, no. 1, pp. 1-15, 2015, doi: 10.1111/1468-2427.12134.

[20] J. Seglow, "The Ethics of Altruism: Introduction," in The Ethics of Altruism, J. Seglow, Ed. London: Portland: Frank Cass Pub, 2004.

[21] K. R. Monroe, The Heart of Altruism: Perceptions of a Common Humanity. Princeton: Pinceton University Press, 1996.

[22] A. Negri and M. Hardt, Multitude. New York: The Penguin Press, 2004.

[23] A. Lubis, "Tren Donasi Digital Meningkat, Donatur Milenial Paling Mendominasi," Jawapos, 2020. https://padek.jawapos.com/bisnis/07/12/2020/tre n-donasi-digital-meningkat-donatur-milenialpaling-mendominasi/ (accessed Feb. 22, 2021). 